\title{
From Industrial Evil to Decent Work
}

\author{
The ILO and Changing Perspectives towards Home-based Labour
}

\author{
Eileen Boris
}

The home has haunted the formulation of global labour standards. It has stood for the space of family privacy, the realm of reproduction, where the woman's responsibility for the quotidian aspects of life and for life itself distinguished her from the male breadwinner. * For nearly a century, the International Labour Organization (ILO) attacked the low wages, long hours, and unregulated conditions of outwork indirectly, sometimes including it in its conventions and other instruments, but more often allowing signatory states to exempt myriad forms of home-based labour from coverage. Beginning in 1919, when the ILO emerged out of the First World War along with the League of Nations, until the 1970s, when global supply chains intensified the relocation of manufacturing to the global South, garment unionists and labour feminists pushed for the elimination of home work. By the last decades of the twentieth century, however, they increasingly called for regulation rather than the prohibition of home-based labour. As the body that established norms for the world of work, the ILO appeared as a venue to gain redress. ${ }^{1}$

It is tempting to label this shift in perspective as a progress narrative: from outwork as an evil to be eradicated to home-based work and home workers as deserving decent work like all other labourers. ${ }^{2}$ This outcome was hardly inevitable, the victory partial, and its timing pyrrhic. Pushed by trade union federations, feminist campaigners, and its own staff, the ILO formulated what became Convention No. 177, "Home Work", which the International Labour Conference (ILC, one of the ILO's component parts) passed in 1996. But this measure extended labour protections to home workers precisely when the old standard employment relationship was fraying. ${ }^{3}$ With more workers even in

* I would like to thank Blair Hull for endowing the Hull Chair in Feminist Studies, which I hold; the archivists and staff at the ILO; research assistant Sharon Dade; and the editors of volume.

1 Gerry Rodgers et al., The ILO and the Quest for Social Justice, 1919-2009 (Ithaca, 2009).

2 Clare Hemmings, Why Stories Matter:The Political Grammar of Feminist Theory (Durham, 2011).

3 David Weil, The Fissured Workplace: Why Work Became so Bad for so Many and What Can Be Done to Improve It (Cambridge, 2014); Leah F. Vosko, Managing the Margins: Gender, Citizenship, and the International Regulation of Precarious Employment (New York, 2010).

(C) EILEEN BORIS, 2022 | DOI:10.1163/9789004499614_009

This is an open access chapter distributed under the terms of the CC BY-NC-ND 4.o license. 
"developed" countries defined as independent contractors and shoved into the informal economy, home work's past began to foretell labour's future. The strategies of home-based workers for survival and recognition thus take on added significance in today's gig economy.

The road to Convention No. 177 requires historicization. The 1980s' recognition of home-based labour as worthy of standard-setting, for which activists in India and elsewhere were central, drew upon key players within and around the ILO: international union federations and the ILO tripartite committee for the clothing industry; the staff in the Programme on Rural Women of EMPLOI, one of the technical sections of the International Labour Office (the Office), and grassroots campaigners. These stakeholders-labour feminists, garment unions, development specialists, ILO staff, and home-based worker campaigners-brought their own goals to the table, motivated by self-interest, feminism, and economic justice. That this pathbreaking recognition of the home as a workplace has garnered few signatories (ten as of 2020 ) should not distract from its impact. It launched international action on other excluded, informal, and "non-standard" workers, and has proven to be an instrument which home workers and their allies, as von Broembsen and Harvey ("Realizing Rights for Home Workers: Participating in Global Supply Chains") emphasize in this volume, have deployed to make changes in national laws and corporate practice.

Scholars and activist commentators have highlighted the role of grassroots and feminist activists who campaigned for the Convention. ${ }^{4}$ Yet NGO s could only become observers with limited participation because of the structure of the ILO. This limit comes from the ILO's unique tripartite structure that divides national representation between government, worker, and employer members. Since employers were adamantly opposed and governments had to be convinced, success depended on the willingness of the global trade secretariats and worker delegates to embrace the cause - though Office staff proved crucial for an insider-outsider strategy. The opening up of the ILO to issues of the informal sector and the problem of multinational enterprises further set the stage for their efforts.

Still, ideas matter. Campaigners confronted assumptions and silences about gender difference, the unequal global development of labour relations, and the relationship of women (and men) to productive and reproductive work at the core of ILO activities. The global labour standards regime of the twentieth century took the conditions of industrial workers, predominantly male, in the

4 Annie Delaney et al., Homeworking Women: A Gender Justice Perspective (London, 2019). 
global North as the norm, turning the woman worker into a problem of difference and treating women in colonialized and developing nations as difference's other, distinct from those in industrial nations. Even though some men also laboured as home-based workers throughout the world, policy-makers judged industrial home work as a feminized practice, conflated with and often discussed with domestic work; the home location of both (and the association of agricultural work with the family farm) obscured commodification and exploitation as these forms of labour became confused with the unwaged family labour of wives, mothers, and daughters. The ILO remained reluctant to address home spaces as places of employment until the self-activities of home-based workers and their advocates forced the issue at the end of the twentieth century. ${ }^{5}$

This chapter divides into four sections. During the interwar years, conventions allowed for outworker exemption. With the United Nations (UN) development decades after the Second World War, action against industrial home work stalled but home handicraft for cultural and social reasons emerged in the ILO imaginary as work most appropriate for women in Asia and other developing regions. The last two sections consider parallel movements: policy pleas of trade union bodies and ILO tripartite committees from the 1970s and the 1980s, and lobbying within the ILo by staff: feminist development experts who sought action from the $1980 \mathrm{os}$ until passage of the Convention. The chapter ends with an analysis of Convention No. 177 itself.

Addressing the first ILC in 1919 on the question of the eight-hour working day, the prominent French trade unionist Léon Jouhaux distinguished between work "in which only members of the family are employed" and home work: "a shameful exploitation, against which vigorous action should be taken". The majority of delegates, men accompanied by a few women advisors, seriously doubted the feasibility of monitoring hours in the home-the number of inspectors needed would be too large. The impossibility of regulation meant that suppression was the only solution. But the very rationale for this

5 For greater elaboration, see Eileen Boris, Making the Woman Worker: Precarious Labor and the Fight for Global Standards, 1919-2019 (New York, 2019), from which a portion of this chapter comes. 
impossibility - the home location - also justified doing nothing out of fear of state "control over private life", as another French delegate insisted. ${ }^{6}$

During the interwar years, the ILO considered industrial home work, often referred to as outwork, in relation to compensation and social protection. Commentators generally agreed that this system of production generated abuse and exploitation: low wages and wage theft, long hours, child labour, unhealthy working conditions, and threats to public health. Coming up with standards was difficult. Member states exhibited uneven and scattered coverage despite legislative, union contract, and administrative models of determining minimum wages. ${ }^{7}$ Some states had viable laws: Australia and Britain long had used wage boards to regulate the sweated trades; Germany strengthened its trade board act in 1923. Norway's experimental act relied on a central Home Work Council whose leaders could not "have any economic interests in the decisions of the Council". With some 4,50o needle workers concentrated around Oslo, agents conducted home inspections to verify working conditions and examine books in which workers and employers recorded items made, hours worked, and payments. ${ }^{8}$ Argentina covered some clothing workers, while Hungry, Canada, and Czechoslovakia claimed to have fixed wages successfully for outworkers. ${ }^{9}$

In the early 1920s, however, not all legislative attempts succeeded. An effort to draft wage and hygiene standards for home work stalled in Belgium. ${ }^{10}$ Sweden argued that decreasing numbers and more robust worker organization made the need for legislation less pressing than it was earlier in the century. ${ }^{11}$ Other states failed to classify home workers as employees, placing them outside of the law. India based its exclusion on the practices of agriculturalists who took in work secondarily, and the self-employed, specifically own-account workers in the handloom industry. ${ }^{12}$

6 League of Nations, International Labour Conference: First Annual Meeting (Washington, 1920), p. 6o; International Labour Conference [hereafter ILC], Minutes of the Commission on Hours of Labour (Geneva, 1923), p. 10. ILC, Minimum Wage-Fixing Machinery: Report and Draft Questionnaire, First Discussion, Item II on the Agenda (Geneva, 1927).

8 Ibid., pp. 88, 91.

9 League of Nations, International Labour Conference, Eleventh Session, I (Geneva, 1928), pp. 401, 383-84, 407; Vivien Hart, Bound by Our Constitution: Women, Workers, and the Minimum Wage (Princeton, 1994).

10 League of Nations, International Labour Conference, Eleventh Session, I, p. 202.

11 ILC, Report on Minimum Wage Fixing Machinery, Second Discussion, First Item on the Agenda (Geneva, 1928), p. 31.

12 League of Nations, International Labour Conference, Eleventh Session, I, p. 411. 
The Office asked in the mid-192os whether states would support a specific recommendation on home-working trades..$^{13}$ As often done, the resulting proposal placed what appeared as a particular practice under an apparently more universal concern. That is, rather than a stand-alone convention, the ILO's Governing Body agreed that a convention on regulating wages would "primarily" cover home-working trades. It would rectify the abuses of home work through the well-established concept of the wage board, setting rates in relation to both general standards and factory equivalents (leaving the determination of equivalency to be resolved). ${ }^{14}$ Wage boards usually consisted of workers, employers, and government members. But experts were central to their determinations, reflecting the privileging of quantifiable knowledge on cost of living that embodied concepts of working-class life and the needs of the woman worker.

ILO delegates agreed that home workers were unable to raise their own standards. They lacked the power to engage in collective bargaining, so the state had to become involved in wage-setting. A German worker advisor argued the case for coverage of home workers, whose numbers in his country were "extensive" in textiles, glass, wood, and metal industries, but were difficult to organize "because they fear to lose their employment".15 To deal with home work as a system of "evasion", as a South African government delegate called it, demanded placing "the same kind of work" carried out in factories and in homes on a similar footing rather than establishing "any special measure of protection". He preferred to abolish the practice and establish crèches to facilitate mothers going out to work. ${ }^{16}$ Feminist Betzy Kjelsberg, a Norwegian government delegate and one of three women (out of forty) on the 1928 committee crafting an instrument, explained that Norway's minimum wage legislation intended not "to repress home work" but rather to fix its wages in light of actual conditions, to cover cost of living "and enable the worker to maintain his working capacity". ${ }^{17}$ The assumption that home workers were weak, ill-informed, and afraid, that they were casual workers supplementing family income, would persist. They were wives and mothers, and thus, by definition, less organizable.

13 League of Nations, International Labour Conference, Tenth Session, I (Geneva, 1927), pp. 657,661 .

14 League of Nations, International Labour Conference, Eleventh Session, I, p. 380; Governing Body, Minutes of the zoth Session (Geneva, January 1926), p. 36.

15 League of Nations, International Labour Conference, Eleventh Session, I, pp. 93, 99.

16 League of Nations, International Labour Conference, Tenth Session, I, p. 407.

17 League of Nations, International Labour Conference, Eleventh Session, I, p. 401; League of Nations, International Labour Conference, Tenth Session, I, p. LXXVII. 
The 1928 Minimum-Wage Fixing Convention (No. 26) applied to "trades or parts of trades" with "exceptionally low" wages without collective bargaining. ${ }^{18}$ It was generally agreed that all low-waged industries could benefit, but countries had considerable leeway in how they applied their mechanisms and calculated an appropriate minimum wage. Some government delegates (from Austria, Denmark, France, the Netherlands, and Rumania) and the employers' group had wished to restrict such machinery to home workers. Employer opposition, as in Japan, to any instrument came from the relative advantage that low wages held in international trade. A male Japanese worker delegate who saw through such arguments accused employers of mislabelling home work as a family "side-business". Middle-men earned special opprobrium for "depriv[ing] the workers of the greater part of the product of labour". Employers in general claimed that home workers themselves rejected state interference "as a violation of their home". 19 There was an irony attached to the employers' group concession to cover home workers. Inclusion of workers located in factories challenged employer prerogative to determine compensation, but trampling employer rights was moot when it came to home workers. The difficulty of monitoring the home limited the impact of wage board or legislative determinations.

Convention No. 26 addressed women's precarious labour through an apparently gender-neutral mechanism, but which everyone recognized was about women's low-waged work and the conditions in families where husbands brought materials home for wives and children to assemble or sew. As a male French employer delegate explained during the first discussion in 1927, "we are dealing with the work of a family. This work is exceptional, not only because of the nature of the trade, but because of the special category of workers employed". ${ }^{20}$ It was to combat women's disadvantaged position in the labour market. Pleaded Miss Wolff of the Berlin Women Home-Workers' Trade Union, a German labour advisor, "There are many women workers in particularhungry women - whose welfare and the welfare of whose children perhaps depend upon getting adequate wages, and thus upon the application of the

18 ILO, "Minimum Wage-Fixing Machinery Convention", 1928 (No. 26), available at https:// tinyurl.com/y4pzw8wk, last accessed 26 November 2020; League of Nations, International Labour Conference, Eleventh Session, I, p. 98; Elisabeth Prügl, The Global Construction of Gender: Home-based Work in the Political Economy of the 2oth Century (New York, 1999), pp. $40-48$.

19 League of Nations, International Labour Conference, Eleventh Session, I, pp. 98-100, 382,384 .

$20 \quad$ League of Nations, International Labour Conference, Tenth Session, I, p. 403. 
machinery provided for". She hoped the question would never come down to "giving the workers, and particularly the women workers, a choice between having very low wages and having no wages at all". ${ }^{21}$ The adopted instruments targeted women-dominated occupations where few men performed the same jobs as women, while reaffirming the principle of equal remuneration. ${ }^{22}$ Recognizing workforces with many women, the accompanying recommendation, No. 30, suggested that there should be a woman among both the worker and "independent" representatives on any wage board. ${ }^{23}$

Regulating home work generated its own special treatment/equal treatment conundrum that has long divided feminists but one in which stakeholders other than the workers themselves defined the options. Feminist proponents of legal equality, institutionally outside of the ILO, made the charge of subversion of the principle of equal pay for equal work without much evidence. ${ }^{24}$ In contrast, Kjelsberg claimed compatibility between wage-fixing and the principle that workers "have the right to a living wage" as well as an equal one. Her statements at the ILO revealed the complexity of feminist thought at that time. She both adhered to legal equality between the sexes and based the authority to defend such principles on her duty as a woman, a special standpoint. ${ }^{25}$ An accompanying non-binding recommendation similarly adhered to female distinctiveness, common among activist women, when requesting that women be included among worker and independent representatives on wage boards, as previously noted. ${ }^{26}$

During the 1930s, conventions on social insurance recognized outwork in their titles but such naming was no guarantee of coverage. The special status of the home formed a barrier. "Compulsory Old-Age Insurance for Persons Employed in Industrial or Commercial Undertakings, in the Liberal Professions, and for Outworkers and Domestic Servants Convention, 1933" (No. 35), despite its title, allowed nations to exempt "outworkers whose conditions of work are not of a like nature to those of ordinary wage earners" as well as "members

21 League of Nations, International Labour Conference, Eleventh Session, I, p. 396.

22 Paula Määttä, The ILO Principle of Equal Pay and its Implementation (Tampere, 2008), pp. 89-92; League of Nations, International Labour Conference, Eleventh Session, I, pp. $441,444$.

23 ILO, "Minimum Wage-Fixing Machinery Recommendation", 1928 (No. 30) available at https://tinyurl.com/59tmfzek, last accessed 29 November 2019.

24 Boris, Making the Woman Worker, chapters 1 and 2.

25 League of Nations, International Labour Conference, Eleventh Session, I, p. 402.

26 Ibid., p. 648. 
of the employer's family". ${ }^{27}$ The same wording limited the applicability of "Invalidity Insurance (Industry, etc.) Convention, 1933" (No. 37) and the earlier "Sickness Insurance (Industry) Convention, 1927" (No. 24), which only mentioned outworkers to allow for their omission. ${ }^{28}$ This wink to nations with no intent to include would repeat in the early postwar years with the extension of maternity protection to home-based workers that allowed for postponing implementation. ${ }^{29}$

Delegates tended to group home workers with domestic workers. In 1936, the ILC voted to delay consideration of these groups, along with agricultural workers, in a Holiday with Pay convention. Without any documentation, the employers asserted the administrative difficulty of including home workers. A concurring resolution underscored both "the present lack of any regulation of the hours of work of these workers" as a justification for paid holidays, and "the special character of the relations between employers and home workers" that required "special arrangements". Home work stood apart from existing regulatory frameworks, which justified exclusion from standards. ${ }^{30}$

\section{Development Decades, 1944-75}

Following the Second World War, during the years when the UN system focused on "third world" development, the ILO explored regulating home labour while advocating home handicrafts for women as a solution to underdevelopment. Questions of trade and factory conditions as well as global competition propelled a fresh look, but the place of the home in culture and society pervaded the discussions. As a French correspondent replied to an Office request for information, "labour inspectors are barred from inspecting the home worker's actual place of work by the principle of the inviolability of private domicile which French social legislation has apparently not modified to any extent". ${ }^{31}$ In

27 ILO, "Old-Age Insurance (Industry, etc.) Convention", 1933 (No. 35), available at https://tinyurl.com/vs64pytm, last accessed 28 August 2019.

28 ILO, "Invalidity Insurance (Industry, etc.) Convention", 1933 (No. 37), available at https://tinyurl.com/2k7x2hph, last accessed 28 August 2019; ILO, "Sickness Insurance (Industry) Convention", 1927 (No. 24), available at https://tinyurl.com/3rt8233j, last accessed 28 August 2019.

29 ILC, “Committee on Maternity Protection", June 1952, ILC 35-510-7, International Labour Organization Archives [herafter ILOA], Geneva.

$30 \quad$ ILC, Record of Proceedings, Twentieth Session (Geneva, 1936), pp. 465, 639.

31 Governing Body, "Correspondence Committee on Women's Work", Minutes, 99th Session (Geneva, September 1946), pp. 70-72; “Industrial Home Work in France”, p. 13, WN1001/06, 
passing a US-initiated "Resolution Concerning Women's Work" as a "tribute" to the wartime labours and sacrifices of women throughout the world, delegates at the 1947 ILC conceived home work (and domestic work) as part of "the problems of the employment of mothers of families". ${ }^{32}$

In the early post-Second World War years, the ILO only researched home work, despite the request for action by the Correspondence Committee on Women's Work. ${ }^{33}$ The Director-General and Governing Board dismissed efforts to do anything else. Calling for more study delayed wrestling with proposals for international instruments. Regarding home work, the Director-General in 1947 felt that "it would be premature for the Office to submit this question pending the actual collection of further information", one of his deputies informed Mildred Fairchild, head of the Section on Women and Young Workers. Instead, he suggested that they publish research authorized by the Governing Body in the International Labour Review. ${ }^{34}$

The subsequent report in 1948 continued the tropes of irregularity and danger. Describing the system as "hazardous", it referred to cheap labour amid rampant falsification of records by both employers and workers, suggesting illegality and illegitimacy. States relied on wage boards, government committees, hours laws, distribution regulations, registration mechanisms, and social insurance rules to monitor the practice. Inspectors more often looked at the employer's books than visited the worker's home. But no one was certain of the results. ${ }^{35}$

Home work loomed over initiatives to bring women of the global South into development by encouraging handicraft industries. In the early 195os, researchers discovered that women "represent a considerable part of the productive capacity of the labour force in handicrafts", though estimating numbers in this mostly informal sector was daunting. Conditions of work were abysmal: long hours, hazardous materials, cramped quarters, and economic exploitation from middle-men. ${ }^{36}$ Because crafts production occurred in the household,

ILOA. For France, Colette Avrane, Ourières à Domicile: Le combat pour un salaire minimum sous la Troisième Républicque (Rennes, 2013).

32 ILC, Record of Proceedings, Thirtieth Session, Geneva, 1947 (Geneva, 1948), pp. 404-06, 236.

33 Governing Body, "Correspondence Committee on Women's Work", p. 72.

34 Fairchild to Miller, 15 January 1947, WN1001/06, ILOA.

35 Governing Body, “Correspondence Committee on Women's Work", pp. 36-37; ILO, "Reports and Enquiries: Industrial Home Work", International Labour Review, LVIII (December 1948), pp. 735-51.

36 Asian Advisory Committee, "Special Protective Legislation Affecting Women and Its Relation to Women's Employment in Asian Countries", pp. 4-6, AAC/IV/D.5, 24, in WN 2/7, ILOA; "Development of Opportunities for Women in Handicrafts and Cottage Industries", IX Session, pp. 13-20, ESC 77-8, ILOA. 
such work posed no challenge to purdah or other cultural or religious practices that secluded women from contact with non-family. This hidden quality, as German feminist researcher Maria Mies later argued in an ILO-supported study, allowed for the obfuscation of women's labour as house work, what she termed housewifization, and thus the denial of their status as workers even when they were producing under orders of contractors for the world market. ${ }^{37}$

The line between handicraft and industrial home work was a shifting one. Blurring especially occurred when the goods produced by independent artisans and self-employed people resembled those made for an employer using "materials belonging to the employer and undertaken on order, tending to turn the home into a sweatshop", charged Frieda Miller of the US Women's Bureau, who was an active member of the Correspondence Committee and often a delegate to the ILC. ${ }^{38}$ With its irregular hours, starvation wages, and proclivity to involve child labour, industrial home work certainly was no solution "to relieve mothers of young children from the necessity of work outside their homes by means of providing paid work they could do in their homes", she contended. In the mid-195os, Miller would serve as an ILO consultant surveying women's work in Asia. ${ }^{39}$ Though she had fought for legislative prohibition in her country, she was open to home-based industry in Asia if authorities safeguarded labour standards. ${ }^{40}$

Pre-Second World War industrial home work, Miller insisted, differed from Asian home-based industry. The first "was a sort of parasitic growth on an established factory system whose purpose it was to escape certain legitimate costs of in-plant production", and to ignore wage, hour, child labour, and safety laws. But Asia's "small scale and cottage industries ... related to capital shortage which makes plant and elaborate equipment hard to get or impossible while the small-scale enterprises substitute underemployed or unemployed workers with a minimum of capital". The Philippines was an exception, with its garment industry, connected to the US economy, full of home work to evade factory law through "exploitative standards". ${ }^{41}$

37 Maria Mies, The Lace Makers of Narsapur: Indian Housewives Produce for the World Market (London, 1982).

38 Frieda Miller to Mildred Fairchild, 15 May 1947, WN1001/06, ILOA.

39 Frieda Miller to Ingeborg Waern Bugge, 30 December 1945, WN 1001/07, ILOA; Frieda Miller, ILO Personnel File P 7353 1955-1957, Jacket 1, ILOA.

40 Eileen Boris, Home to Work: Motherhood and the Politics of Industrial Homework in the United States (New York, 1994), pp. 247-52.

41 Frieda Miller to Eugene Staley, 31 October 1958, Box 13, Folder 257, A-37, Schlesinger Library, Radcliffe, Cambridge, MA. 
The dangers of home work pervaded most discussions on handicraft. Scattered in "private" homes, unregulated and unorganized, and performed by women (often joined by their children) without other options for income and who find it "convenient" to work from home, such labour was ripe for abuse. The ILO staff worried about how to protect handicraft workers "against exploitation by middlemen and against sweated conditions of industrial homework". ${ }^{42}$ They suggested developing local supplies of raw material and alternative sources of credit, especially through cooperatives, to eliminate the middle-man. They advised bringing such work under national laws, despite being "easily evaded". ${ }^{43}$ The UN Commission on the Status of Women asked the ILO in 1956 "to give special attention to methods found useful to organize on a sound basis handicrafts and cottage industries products", so "to avoid the evils of industrial home work". 44

Sectoral committees of the ILO wrestled with the threat of home work undermining factory conditions. These committees brought together Government, Worker, and Employer representatives to discuss conditions in specific industries. ${ }^{45}$ The textile trade regularly held tripartite deliberations in the postwar years, but it took lobbying by international union federations, and organized US employers and garment workers, to institute a committee for clothing in 1964. Sixteen years would pass before a second meeting, delayed in part by the economic constraints affecting the sector, which also impeded ILO operations. ${ }^{46}$

The very characteristics of clothing and related industries-"low capital requirements and the ease with which part of the work can be done at

42 Outline, "Development of Opportunities for Women in Handicrafts and Cottage Industries", p. 1, ESC 77-8, ILOA.

43 "Opportunities for Women in Handicrafts and Cottage Industries: Progress Report prepared by the International Labour Office" for x Session, pp. 2-4, ESC 77-8, ILOA.

44 "Note for the Governing Body, 135th Session: Tenth Session of the UN Commission on the Status of Women", p. 7, ESC 1004-11-10, ILOA. ILO capitalizes Employer, Worker, and Government when referring to representatives or delegates.

45 ILO, 1964 Tripartite Technical Meeting for the Clothing Industry, General Examination of the Labour and Social Problems in the Clothing Industry, Report I (Geneva, 1964), p. 3; ILO, Second Tripartite Technical Meeting for the Clothing Industry, Contract Labour in the Clothing Industry, Report II (Geneva, 1980), p. 1, all in ILOA. Subsequent reports are also found in the ILOA. ILO, 1964 Tripartite Technical Meeting for the Clothing Industry, pp. i-iii. 
home" - generated nervousness that the practice flourished despite assertions that industrial home work had "declined in recent years". When responding to Office inquiries in the 1960s and 1970s, nations quantified the extent of home work but could not vouch for the accuracy of their calculations. ${ }^{47}$ Much of the production occurred "under the table", as a manoeuvre around trade restrictions, labour standards, and even worker compensation. After the Second World War, home work expanded in newly industrializing regions and offshoring intensified. Reacting to these conditions, the ILO issued a declaration in 1977 on multinational enterprises and their social responsibilities, prefiguring later measures to regulate global supply chains. ${ }^{48}$

Organized workers recorded similar trends. While everyone agreed that women with family responsibilities took in work to earn necessary income, few questioned the assignment of domestic and care work to women. Some affiliates of what in 1972 had become the International Textile, Garment, and Leather Workers Federation (ITGLWF) associated home work with minoritized or dependent groups. The Indian Textile Labour Association (TLA) pointed to "very large numbers of Muslim and other caste women", while US unions connected home work to immigrants from Asia and the Americas (earlier Eastern and Southern Europeans and Puerto Ricans had predominated as outworkers). ${ }^{49}$ By the end of the decade, the new Federation boasted 5 million members in 140 unions from 70 countries, numbers that were less than impressive given that there were millions more toiling in these trades. ${ }^{50}$ Recognizing unique national circumstances, the Federation hoped to level the playing field through global labour standards while aiding global South affiliates. As one Federation leader insisted, "It is obvious that unions must try to organize all workers, whether they are in factories or at home". ${ }^{51}$ But that was easier said than done, given the scattered and episodic form of the labour, the belief

47 Ibid., pp. 34-35, 45, 64-65; ILO, Second Tripartite Technical Meeting for the Clothing Industry, pp. 9, 19, 21-22.

48 Prügl, The Global Construction of Gender, p. 102; "The Multinational Enterprises Declaration", available at https://tinyurl.com/say7uwx6, last accessed 27 August 2019.

49 International Textile, Garment, and Leather Workers' Federation [hereafter ITGLWF], Report on Homework (Brussels, 1 June 1978), p. 10; ITGLWF, Employment of Women in the Textile, Garment, and Leather Industries (Brussels, 1980), pp. 19-20.

$5^{\circ}$ Charles Ford, Transcript of the Third Sitting, 26 September 1980 Afternoon, p. III/102, IC 17-2-202, ILOA.

$5^{1} \quad$ ITGLWF, Second World Congress, 22-26 March 1976 (Brussels, 1976), p. 188. 
that these women were not real workers, and the male domination of union leadership.

Sectoral committees of the ILO, which included union delegates, usually proceeded by consensus. Under discussion at the First Tripartite Meeting of the Clothing Industry in 1964 were general conditions of work and social problems that characterized the industry. ${ }^{2}$ Employers and workers failed to agree on how to combat home work; the meeting passed a resolution by majority vote rather than unanimously. Employers, workers, and governments were able to concur that "there should be maximum governmental regulation and control", which included registration of employers, middle-men, and workers. But many employers and a few governments still rejected the central claim that the practice "should, as a matter of principle, ultimately be abolished, except as to certain individuals - for example physically handicapped persons - who cannot adapt themselves to factory work". The resolution insisted that prior to abolition, labour standards and social protection for home workers should match those of their factory counterparts. Meanwhile, the ILO should study the problem. ${ }^{53}$

This resolution provided authority for a subsequent measure passed by the Second Congress of the ITGLWF in 1976. The international union "reaffirm[ed] its opposition to the evils of industrial home work", requested affiliates "to press their governments to pursue policies leading to the ultimate abolition", but, until that time, called for "the same legal status as factory workers ... with full entitlement to social benefits". To enforce parity, it demanded full registration of "home workers, agents, and employers". In contrast to the ILO sectoral committee, its resolution maintained the discourse of disgust and outrage that for long had pervaded writings against the sweatshop. It spoke of "evils", "threat", and "pittance". It portrayed workers as "deprived", using language like "appalling" and "deplorable" to describe their fate. Other reports deployed coercion metaphors, referring to "slave labour", "near-slavery", and "people chained". ${ }^{4}$

Nonetheless, the garment unionists were pragmatists. Apparently maintaining a single standard for the developing and developed nations in an era when the Cold War and decolonization challenged western hegemony was more prudent than pushing for immediate abolition. By taking the lead, the US affiliates (International Ladies' Garment Workers Union/ILGWU, Textile Workers Union of America, and Amalgamated Clothing Workers of America) could keep some control over the political process of resolution-making. Arvind Buch, president

\footnotetext{
$52 \quad$ ILO, 1964 Tripartite Technical Meeting for the Clothing Industry, p. 35.

53 ILO, Second Tripartite Technical Meeting for the Clothing Industry, p. 1.

54 ITGLWF, Report on Homework, pp. 1-6, 38-9.
} 
of the India TLA, called for organizing the self-employed, reflecting the activities of its women's section under Ela Bhatt. ${ }^{55} \mathrm{~A}$ few years later, Buch would expel Bhatt's group, which led her Self Employed Women's Association (sEWA) to form close connections with ILO staff and NGOs who pushed forward a home work convention, as we shall see.

The 1980 Second Tripartite Meeting of the Clothing Industry repeated previous calls. It concluded that nations needed to clarify the legal status of such workers, regulate the practice, and limit it "to specific cases where home workers are unable to earn income in any other way". While wanting prohibition ultimately, the resolutions also asked for equivalence between shop and factory workers in terms of wage determination and minimum wages; social security, unemployment, and health benefits; and statutory standards for health, safety, and hours. Holding banning homework and regulating it simultaneously was not contradictory since the general belief was that home work persisted because it was unregulated and cheaper than factory labour; raise its costs, and its advantage for employers would disappear. Lack of direct supervision led to imperfect quality control, which would no longer be merely wasteful but would also become burdensome with regulation. So work would return to factories or workshops. Other items addressed specialized labour inspection and recording of work; "vigilance" with respect to child labour and "illicit or clandestine home work"; "cooperation" among social partners in "control and supervision"; and trade union rights. Finally, the assembled delegates recommended the "possibility of adopting international labour standards concerning home workers" - a tentative gesture towards ILC action. ${ }^{56}$

Tripartite meetings tended to attribute ineffective regulation to unscrupulous contractors and other employers who refused to keep mandated records and cheated workers, rather than to structural problems from offshoring and outwork. ${ }^{57}$ But workers knew otherwise. Their livelihoods depended on regulating home work. They were acutely aware of displacement from industrialized to developing countries fuelled by multinationals operating from industrial centres. To avoid exploitation and maintain job security, unionists throughout the world had to demand "fair labour standards" as part of all trade agreements and development programmes. ${ }^{58}$ Meanwhile the old gender

55 ITGLWF, Second World Congress, pp. 187-88; ITGLWF, Report of the First World Congress (Brussels, 1972), p. 10.

$56 \quad$ ILO, Second Tripartite Technical Meeting for the Clothing Industry, p. 74.

57 For example, Mr Bedoya, Transcript of Fourth Sitting, p. IV/42, ILOA.

58 Joint Congress of the International Shoe and Leather Workers' Federation and the International Textile and Garment Workers' Federation (London, 1970), p. 8, Library, US Department of Labour, Washington, D.C. 
justification for home work, that women choose to take work home to earn supplementary incomes while caring for the family, persisted across political economies. Women trade unionists in the International Confederation of Free Trade Unions (ICFTU) and International Trade Secretariats rejected such a rationale. They agreed "that part-time, temporary or home work" provided no "effective solution to the problems" facing workers with family responsibilities, then under reconsideration by the ILO. ${ }^{59}$

Employer disgruntlement foreshadowed the contentious process that erupted when the ILO entertained standard-setting. Worker delegates (along with governments of socialist states) had lashed out against multinational corporations and, later, worried about the impact of structural adjustment on living standards. In response, at the 1980 Clothing Committee, a UK employer complained,

We do not believe that we are being oversensitive, but the whole tenor of the presentation seems to us never to miss an opportunity to attack employers in a way which we feel generally diminished the credibility and indeed the impartiality of the ILO to the advantage of no one including the interests of workers, and we would urge, Mr Chairman, that a greater sensitivity be paid to this in future. ${ }^{60}$

The Employers' group rejected abolition of home work "even in the long term". They admitted to having "strong reservations" against the earlier 1964 resolution due to the belief that "home work could play an important role both for the enterprises that resorted to it, as well as for a number of workers". ${ }^{\prime 1}$ At the Third Tripartite Meeting in 1987, though the Employers' group condemned illegal home work, "performed not in accordance with laws or other protections" and kept from taxation or social security contributions, it agreed "that legitimate home work was a necessary feature of the clothing industry". 62

Employers had no problem with laws that defined the home worker as selfemployed or an independent contractor, depriving them of minimum wages and social security, and placing them outside of health, safety, and hours restrictions. They tried to classify these workers as both micro-entrepreneurs

59 “October 4-5, 1979-ICFTU/ITs Consultative Committee on Women Workers' Questions", in ITGLWF, Report on Activities, Third World Congress (Brussels, 1980), p. 48.

6o Transcript of the Eighth Sitting, 2 October 198 o afternoon, p. vIII/4, IC 17-2-202, ILOA.

61 ILO, Second Tripartite Technical Meeting for the Clothing Industry, September-October 1980, Paragraph 43, Note on the Proceedings (Geneva, 1981), p. 24, ILOA.

62 ILO, Third Tripartite Meeting, 1987, Note on the Proceedings, p. 48. 
conducting independent businesses and housewives labouring for supplemental income, that is, non-workers. Such definitions created their own obstacles. If the home worker was not an employee, the only justification for entering her home was public health. But scattered workplaces required an army of inspectors even with complaints by unions, consumers' organizations, and women's groups. Even then the ideological sacredness or privacy of the home in many nations created a political if not legal barrier.

Workers also were disgruntled over the outcome of ILO's sectoral deliberations. The 1984 Third Congress of the IT GLWF unanimously charged the Second Tripartite meeting with "retrogression" for reflecting employer demands, accommodating governments where the practice continued, and for no longer speaking in terms of abolition. The Federation once again committed to eradicating "the evils of industrial home work as a threat to the well-being of workers throughout the world", and requested affiliates to seek abolition in their nations. This proposal, urged by the US affiliates, occurred in the middle of the ILGWU fight against attempts by the Reagan administration to lift all federal bans on garment home work. ${ }^{63}$

The move away from abolition/prohibition represented an altered strategy, an accommodation made to the growth of home work. ${ }^{64}$ The Canadian section of the ILGWU, the Argentinean National Union of Clothing and Allied Workers, and the UK General and Municipal Workers' Union sought to improve conditions for home workers, while home work sections or unions developed in Venezuela, Uruguay, and India. By the mid-198os, unions in Australia, India, UK, Netherlands, and Belgium pushed for covering home workers under existing legislation or adopting new laws for them. The Belgian Confederation of Christian Trade Unions, in contrast, never relented from its belief that home work was "a permanent form of 'blackmail' to reduce [union] claims".65

63 ITGLWF, Report on Fourth World Congress (Brussels, 1984), pp. 105, 163-65; Boris, Home to Work, pp. 337-61.

64 Jane Tate, "Introduction to Part III", in Margaret Hosmer Martens and Swasti Mitter (eds), Women in trade unions: Organizing the unorganized (Geneva, 1994), pp. 63-64.

65 Luz Vega Ruiz, “Homework: Towards a new regulatory framework?" International Labour Review, 131:2 (1992), pp. 212-13; Gisela Schneider de Villegas, "Home work: A case for social protection", International Labour Review, 129:4 (1990), pp. 429-31; Alexandra Dagg, "Organizing Homeworkers into Unions: The Homeworkers' Association of Toronto, Canada", in Eileen Boris and Elisabeth Prügl (eds), Homeworkers in Global Perspective: Invisible No More (New York, 1996), pp. 239-58; Jane Tate, “Canada", in Women in Trade Unions, pp. 77-79; ILO, Meeting of Experts, Social Protection of Homeworkers, 1990 (Geneva, 1991), p. 27. 
Feminist campaigners in the UK and Netherlands had pushed their unions, which later provided them access to the ILO.

The 1987 Third Tripartite meeting maintained the question of home work before the ILO. It asked nations to regulate home work, legalize the status of home workers, and involve employer and worker organizations in ending mistreatment. Significantly, it requested that the Director-General convene an "envisaged Tripartite Meeting of Experts on Home Work as soon as possible".66 Such appeals displayed the kind of global concern that the ILO's Governing Body required to justify action. The Governing Body previously had dropped a meeting planned for 1989 "because of resource constraints". During a period of limited revenues other issues had greater priority, a ranking which suggests that some quarters were unconvinced still about moving on home work. ${ }^{67}$ Workers, however, wanted "urgent attention". By the end of the 1980s, as the ITGLWF's Charles Ford explained, it was abundantly "clear not only that workers' standards in the least developed countries fail to improve to reflect greater productivity and exports but standards in importing countries are being undermined by efforts to undercut imports through return to sweatshop and home-work production". ${ }^{6}$

The international union federations and trade secretariats spoke about industrial home work, but feminist staff within the ILO shared a broader understanding of home-based labour, gleaned from research undertaken on rural women in the global South, often by investigators from the region. These development feminists, located in the Programme on Rural Women and in regional field offices, especially Southeast Asia, pushed for regulating home work from within the bureaucracy. In the $198 \mathrm{os}$, they partnered with grassroots groups to improve women's lives in the informal sector by investigating the "new putting out system". ${ }^{69}$ Through a series of seminars and donor-funded projects, the ILO enhanced the capabilities of rural women's organizations in India, Thailand,

66 ILO, Third Tripartite Meeting, 1987, Note on the Proceedings, p. 92.

67 Ibid., pp. 18-19; ILO, Fourth Tripartite Meeting, General Report (Geneva, 1995), p. 94, ILOA.

68 ILC, Proceedings, Seventy-Fifth Session, 1988 (Geneva, 1989), pp. 16/44.

69 Eileen Boris, "Accounting for Reproductive Labour: Feminist Economists and the Construction of Social Knowledge on Rural Women in the Global South", in Kenneth Lipartito and Lisa Jacobson (eds), Hidden Capitalism: Beyond, Below, and Outside the Visible Market (Philadelphia, 2019), pp. 44-63. 
Pakistan, Indonesia, and Philippines, the most important being SEWA in Gujarat, India. The feminist development staff at the ILO defended Ela Bhatt and her organization after SEWA's expulsion from the TLA. They convinced others in the Office to fund SEWA projects, but had to prove that SEWA was a trade union and not some other formation. ${ }^{70}$

In early 1982, Dharam Ghai, chief of the Rural Employment Policies Branch $(\mathrm{EMP} / \mathrm{RU})$, explained that his unit was "initiating a whole new line of research on home-based industries" due to the results of a project funded by the Programme on Rural Women. He was referring to Mies's "Housewives Produce for the World Market: The Lace Makers of Narsapur", a pathbreaking effort that not only illuminated the workings of the sexual division of labour and intertwining of productive and reproductive labour, but also highlighted the exploitation of the lace makers and the difficulty of organizing a group perceived to be just housewives. ${ }^{71}$ In 1980, along with a working paper by Mies, his unit also released a study by Indian sociologist Zarina Bhatty, "Economic Role and Status of Women: A Case Study of Women in the Beedi Industry in Allahabad". ${ }^{72}$ Bhatty questioned "the commonly advocated policy of seeking to create employment opportunities for women which allow them to remain at home". ${ }^{73}$ Mies demonstrated that a home-based "strategy, by not transforming the production and reproduction relations, may lead to the impoverishment of the women, and a polarization not only between classes but between men and women as well".74 Over the next few years, Ghai and the women running

70 Zubeida Ahmad, "RBTC Rural Development 1982-83: Request for Funding of SEWA's Action Research Proposal, 'Issues of poor self-employed women' ", 13 July 1983, RL 333-100, Jacket 1, ILOA; Mal Mukherjee, "Request for Funding of SEWA's Action Research Proposal", 22 July 1983, RL 33-3-100, Jacket 1, ILOA; Zubeida Ahmad, "SEWA", 28 July 1983, RL 33-3-100, Jacket 1, ILOA.

71 Ghai to Petitpierre, Minute Sheet, 24 March 1982, wE P 10-4-04-33-1 Jacket 1, ILOA; Ahmad to Ghai, Minute Sheet, 8 January 1980, WEP 10-4-04-33-1 Jacket 1, ILOA; Ghai to Beguin, 2 April 1989, WEP 10-4-04-33-1 Jacket 1, ILOA; Maria Mies, "Housewives Produce for the World Market: The Lace Makers of Narsapur", World Employment Programme Research Working Paper, December 1980 (Geneva, 1980), ILOA; published by Zed Press as The Lace Makers of Narsapur: Housewives Produce for the World Market (London, 1982].

72 Zarina Bhatty, "The Economic Role and Status of Women: A Case Study of Women in the Beedi Industry in Allahabad", World Employment Programme Research Working Paper, December 1980 (Geneva, 1980), ILOA; published as The Economic Role and Status of Women in the Beedi Industry in Allahabad, India (Fort Lauderdale, 1981).

73 Dharam Ghai, "Preface", in Bhatty, The Economic Role and Status of Women, p. ii.

74 Dharam Ghai, "Preface", in Mies, The Lace Makers of Narsapur, p. x. 


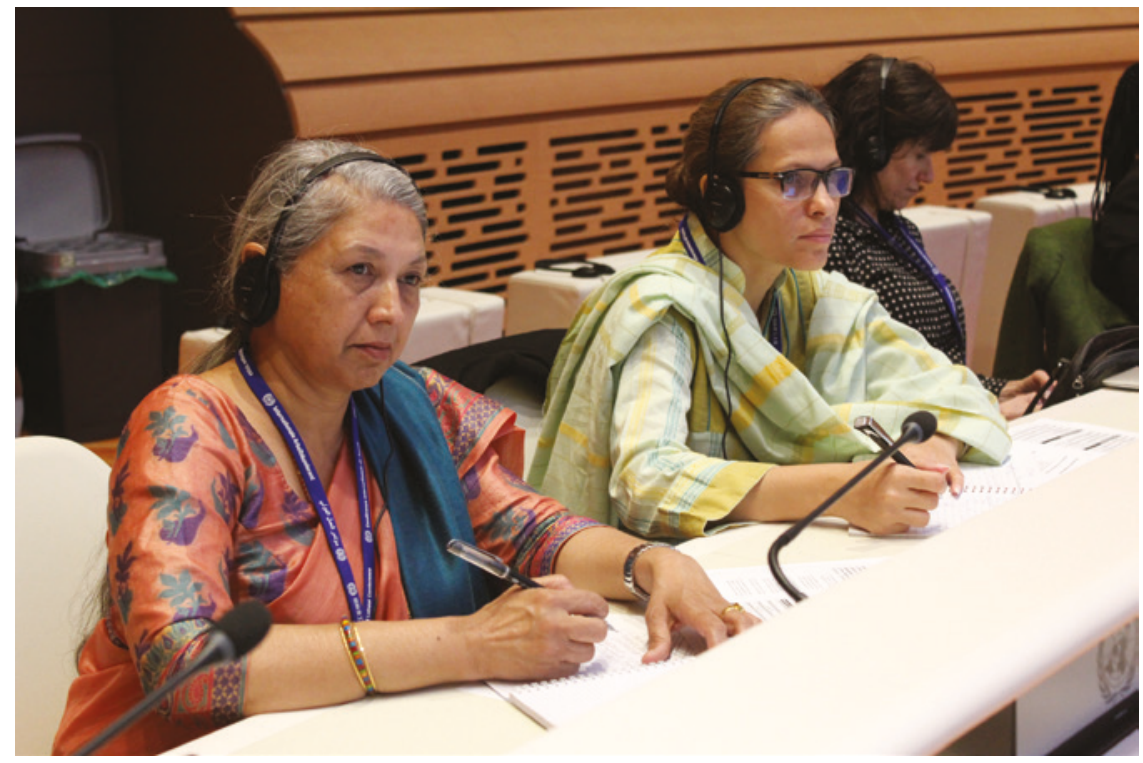

FIGURE 7.1 Homebased workers representatives during the discussion on Supply Chains at the International Labour Conference in Geneva in June 2016 where a small group of homebased workers participated with WIEGO

the Programme, Zubeida Ahmad and Martha Loutfi, cited Mies and Bhatty to justify standard-setting for home-based labour. ${ }^{75}$

On the basis of these investigations, Ahmad and Loutfi announced that "home-based industries in which women work as contract labour" would constitute a major initiative of the Programme. What to call the practice was in flux, as they spoke of cottage industry, home-based industry, home work, outwork, domestic outworkers, contract work at home, and the putting out

75 For example, Zubeida M. Ahmad, "Employment Opportunities for Poor Women in Rural Areas in Developing Countries", Talk 1980, WEP 10-4-04 Jacket 9, ILOA; Zubeida M. Ahmad, "Mission to Bangkok", 24 August 1982, 4, WEP 10-4-04 Jacket 12, ILOA; Martha F. Loutfi, "Mission, Netherlands", 31 August 1982, WEP 10-4-04 Jacket 13, ILOA; Martha F. Loutfi, "Mission, Belgrade", 14-17 November 1982, 2, wE P 10-4-o4 Jacket 14, ILOA; Martha F. Loutfi to Mr Richards, 22 October 1982, WEP 10-4-04 Jacket 14, ILOA; Martha F. Loutfi, "Mission, Washington, D.C., 12-20 October, 1983", WEP 10-4-04 Jacket 16, ILOA; Martha F. Loutfi, "Mission London, 15-19 April 1984", WEP 10-4-04 Jacket 19, ILOA. See also, Eggar to Ms. Belinda Leach, 31 July 1985, WEP 10-4-04 Jacket 25, ILOA, which cites Mies. For the studies' influence elsewhere, see also, Margaret Owen to Martha F. Loutfi, 8 November 1982, WEP 10-4-04-018, Jacket 1, ILOA. 
system. ${ }^{76}$ Ahmad and Loutfi proposed to commission further case studies and then "to review existing international instruments (Conventions and Recommendations) together with national laws and regulations and their relevance to the situation of women who are forced by social and economic circumstances to work on contract at home".77 The staff in Geneva pursued the findings of ILO officials and researchers in the New Delhi and Manila regional offices. Into the early 1990s, they shaped ILO multilateral-bilateral projects on technical cooperation as "Self-Employment Schemes for Female-Headed Households" and "Employment Promotion and Social Protection of HomeBased Workers in Asia". As a SEwA organizer referred to ILO New Delhi staffers Anita Kelles-Viitanen and Andrea Singh, "We are colleagues and crusaders together for a common cause". 78

The Programme pushed other Office units to address the issue. Action required calibrating biennial plans a year or two in advance. As early as 198081 , in response to sectoral industrial committees, the Working Conditions section (CONDI/T) planned country monographs, though budget considerations delayed them. The Programme placed home work in its 1982-83 plan, but other units dallied. In 1981 Ahmad told an informal meeting that theirs was "a fairly long-term programme which may ultimately culminate in an item on the agendas of either regional or international ILO conferences". ${ }^{79}$ In late 1983 , Loutfi recommended moving through the ILO bureaucracy to bring the subject to the Governing Body and then, after a questionnaire and draft instrument that EMP/RU would prepare, proposing a convention and/or recommendation in time for the 1986 ILC. Given the worldwide increase in home work but omission of home workers from legal or union protection, and the inability of existing standards on minimum wage-fixing and maternity to reach home workers, she argued that a convention was "a potentially valuable mechanism to improve the conditions of such workers". A basis already existed to formulate a convention from recent legislation enacted by industrialized nations, though the conditions of developing nations required additional discussion. The goal would be the extension of rights that workers in the formal sector

76 Zubeida M. Ahmad and Martha F. Loutfi, ILO Programme on Rural Women (Geneva, December 1980), p. 14 .

77 Ibid.

78 Anita Kelles-Viitanen to Azita Berar-Awad, 22 January 1992, WEP 10-4-04-028-158, Jacket 3, ILOA; “The Home-Based Are Workers Too", draft typescript, p. 11, WEP 10-4-04-158, Jacket 2, ILOA.

79 ILO, Programme and Budget for the Biennium, 1980-1981, Fifty-Seventh Financial Period (Geneva, 1979), p. 9o/10; Ahmad to Mr Sidibé, Ghai et al., 7 August 1981, WEP 10-4-04Jacket 11, ILOA; Sidibé to Ahmad, 29 September 1981, WEP 10-4-04 Jacket 11, ILOA. 
enjoyed. "Basically, a convention 'would grant to the home worker the rights of 'employee'", she argued. ${ }^{80}$

Loutfi and Ahmad shared their findings with units on laws, standard-setting, convention adherence, women, and health. ${ }^{81}$ They approached higher-ups, Assistant Director-General Antoinette Béguin and Felice Morgenstern of the Legal Division. In early 1984, Loutfi noted, "Perhaps the extent of ILO capability and planned work relevant to this subject is not sufficiently known and shared". She was not one to shy away from the difficulties of confronting a system whose very organization kept workers invisible or a bureaucracy that slowed down redress. "It is our view that the few references to and weak data on home-based producers are not an indication of an unimportant, minor problem, but the contrary". If the ILO was to live up to its commitment to disadvantaged workers, a "fresh look at possible instruments" was needed because of "the apparent ineffectiveness of the traditional response of prohibiting home-based work and contractor arrangements". EMP/RU had undertaken the field work not only to "define the problem but also [to] identity mechanisms for achieving improved protection"; it had charted innovative programmes. Thus she asked her colleagues to "agree in principle to pursue the possibility of formulating a convention and recommendation in this area".82

Loutfi initiated an inter-departmental task force, which, under the leadership of the standard setting department proceeded far more slowly than she wished. ${ }^{83}$ The Programme planned reviews of instruments protecting homebased workers and several workshops during $1984-85$ on self-employment; CONDI/T started to look at industrialized countries. ${ }^{84}$ In early 1985 , she circulated preliminary findings on legal status and summaries on relevant sessions from the "Asian Conference on Women and the Household".85 Other

8o Loutfi to Ahmad, Ghai, Martin, "Items for First Discussion at 72nd (1986) I.L.C"., 19 December 1983, with "Proposal for development of an instrument (Convention/ Recommendation) concerning homeworkers (domestic outworkers)", WEP 10-4-04-018, Jacket 1, ILOA.

81 Informal workshop, "Laws and Policies affecting Home-based Workers under a PuttingOut System", 2 December [1983], WEP 10-4-04-o18, Jacket 1, ILOA.

82 Loutfi to Ahmad, Ghai, Martin, "Agenda for 72nd (1986) Session of the Conference", 1 February 1984, WEP 10-4-04 Jacket 18, ILOA.

83 Loutfi, note for file, “Social Protection of Home-Based Workers, '86-87' ", 23 July 1984, WEP 10-4-04-o18, Jacket 1; Loutfi to Ahmad, Ghai, Martin, 3 December 84, WEP 10-4-04, Jacket 22, ILOA.

84 "1984-85 Regular Budget Work Programme: Employment of Rural Women", WEP 10-4O4 Jacket 18; "Progress Report on SAREC-Financed Research", 1984, WEP 10-4-04 Jacket 21, ILOA.

85 Loutfi to Rahman, Ghai, Martin, Sidibé et al., "Social protection of home-based producers", 27 February 1985, WEP 10-4-04-018, Jacket 2, ILOA; Andréa Menefee Singh and Anita 
departments not so subtly suggested that her program respect other units who worked on the informal sector and self-employment. Loutfi responded by pointing out that the "encouraging" organizing of workers was no reason to reject an ILO instrument as "a valuable tool complementing and supporting practical action by trade unions and other workers' organisations". Indeed, worker groups had called upon the ILO to consider legal measures. She offered as evidence "requests" from SEWA and a recent resolution by the International Union of Food, Agricultural, Hotel, Restaurant, Catering, Tobacco, and Allied Workers' Association (IUF), which SEWA had organized to increase pressure on the ILO. ${ }^{86}$

The task force determined standard-setting to be premature without a more substantive research base. So the Programme published additional working papers on carpet-weavers in rural Turkey, electronic assemblers in Kerala, and rural home work in Latin America. ${ }^{87}$ LEG/REL (Legal Regulation) studied precarious employment in 1984-85 and focused on home work in both industrialized and developing countries for $1986-87$ to determine if these workers came under labour legislation, collective agreements, or other measures. It questioned whether such workers actually fell into the category of persons working in an enterprise. A number of key branches, including Working Conditions and Environment (known as PIACT), planned to study work uncovered by standards in developing countries, including home work. Office staff drew upon various unpublished country reports for summary articles and "Condition of Work" digests. Comparative analysis, they believed, could lead to adopting new standards. ${ }^{88}$ Meanwhile, ILC resolutions on employment and gender equality

Kelles-Viitanen, Invisible Hands: Women in Home-based Production (New Delhi, 1987). This collection prefigured Shelia Rowbotham and Swasti Miller, Dignity and Daily Bread: New forms of economic organizing among poor women in the Third World and the First (London, 1994), and Eileen Boris and Elisabeth Prügl, Homeworkers in Global Perspective: Invisible No More (New York, 1996).

86 K.T. Samson to EMP/RU, 16 May 84 (really 85), WEP 10-4-04-018, Jacket 2, ILOA; Loutfi to Samson, 10 May 1985, WEP 10-4-O4-o18, Jacket 2, ILOA; Hilary Kellerson to EMP/RU, 8 May 1985, WEP 10-4-04-018, Jacket 2, ILOA; Arturo Bronstein to Yemin, EMP/RU (Loutfi), 15 May 1985, WEP 10-4-O4-018, Jacket 2, ILOA; A. Taqi to Ghai, 24 May 1985, WEP 1O-4-O4-o18, Jacket 2, ILOA; Rounaq Jahan to Ghai, 12 June 1985, WEP 10-4-04-018, Jacket 2, ILOA.

87 Gunseli Berik, Women Carpet Weavers in Rural Turkey: Patterns of Employment Earnings and Status (Geneva, 1987), ILOA; Gita Sen and Leela Gulati, "Women workers in Kerala's electronic industry”, WEP Working Paper No. 45 (Geneva, March 1987), ILOA; Maria de los Angeles Crummett, "Rural Women and Industrial Home Work in Latin America: Research Review and Agenda", WEP Working Paper, 46 (Geneva, 1988), ILOA.

88 ILO, Programme and Budget for the Biennium 1986-87, Sixtieth Financial Period (Geneva, 1985), pp. 8o/7, 90/17-18, ILOA; Prügl, The Global Construction of Gender, pp. 110, 191-92, n.31; on legal, H. Boukris, "Conclusion", 2 WEP 10-4-04-018 Jacket 2, ILOA. 
in the mid-1980s and on rural employment promotion in 1988 called for improving the conditions of home work; the 1985 resolution on equal opportunities specifically invited future standard-setting. ${ }^{89}$ It would take another decade for the ILC to begin a first discussion. Ahmad had retired and Loutfi long left the Programme for other assignments, but new staff, like Rounaq Jahan and Azita Berar Awad, pursued the issue. ${ }^{90}$

Action on home-based labour came as the ILO sought to promote selfemployment in the face of unemployment. In June 1990, the ILC passed a broad resolution recommending appropriate labour standards and support for worker organization. The Workers' group pushed for "special measures" to protect home workers and others who were "pseudo self-employed". During general discussion, the ITGLWF's Ford offered a far less positive portrait of such workers than champions of self-employment. He evoked the "'exploitation' of women in Ahmedabad, India, who spend 15 to 18 hours a day hunched over ancient sewing machines, in order to earn 50 US cents". Repeating the historic tropes of the home as factory, childhood denied, and "family life ... tethered to the ever-present work," he urged prompt ILO action on a convention that would soon put home workers on par with factory workers, and regulate "the health and well-being of those forced to work at home". Regulating home work stood as a doable response to the intensified challenge the garment and textile sector faced from free trade zones and globalization untethered from any "social clause". ${ }^{1}$

The ILO also discussed home work as it confronted what the then DirectorGeneral Michael Hansenne named "The Dilemma of the Informal Sector". An ILO study had highlighted the irregular, casual, and hidden work of most of the world's people back in the 1970s, bringing the concept into development discussions. Though contributing to economic growth, the informal sector by definition was open to exploitation and other abuses. But it was also a location of economic activity that generated livelihoods. ${ }^{92}$ The Nordic countries,

$89 \quad$ ILC, Record of Proceedings, Seventieth Session (Geneva, 1984), p. 37/6; ILC, Record of Proceedings, Seventy-First Session, 1985 (Geneva, 1986), p. 40/3; ILC, Record of Proceedings, Seventy-Fifth Session (Geneva, 1988), p. XCvi; see also, ILO, Meeting of Experts, Social Protection of Homeworkers, 1990 (Geneva, 1991), p. 1.

90 Rounaq Jahan to Mr Taqi, 13 June 1985, WEP 10-4-04-018, Jacket 2, ILOA; Azita Berar-Awad, Mission to Philippines, 12 July 1991, for "Rural Women Workers in the New Putting Out System", ACD 53-O-O4, ILOA.

91 ILC, Record of Proceedings, Seventy-Seventh Session, 1990 (Geneva, 1991), pp. 7-15, 32/7, 19/38-19/39.

92 Prügl, The Global Construction of Gender, pp. 79-80; ILO, Employment, incomes and equity: a strategy for increasing productive employment in Kenya (Geneva, 1972). 
the very nations that funded Programme projects, submitted to the ILC in 1991 a resolution on women workers in the informal sector that asked the ILO to expand "documentation of the conditions of life and work of home-based workers and self-employed women", as well as to consider extending social protection, training, and aid to organize them. Other proposed resolutions targeted the informal sector more generally. ${ }^{93}$ During the ILC's first discussion on home work in 1995, the Minister of Labour of Nicaragua would evoke this earlier consideration of informality and its relationship to structural adjustment in arguing for finally confronting the "exploitation which liberalism is imposing in all sorts of countries at this time" through home work regulation. "We are all employers here" ironically underscored the employment relations that many from the Employers' group continued to deny. ${ }^{94}$ The experts already had situated home work as part of "increasing casualization of labour, and particularly its impact on women", and so pointed to both discrimination and public policies that disadvantaged women, particularly in terms of family-care work across generations. ${ }^{95}$

With support from the IUF, ICFTU, ILO development feminists, and some national trade unions (especially in Britain and Netherlands), home work became an agenda item at the ILC. The efforts of SEWA and other women campaigners occurred amid the shift away from viewing home work as so evil that it only could be abolished. Direct appeals to the ILo's Director-General had an impact. Writing after a visit to India to the General Secretary of the ICFTU, then Director-General Francis Blanchard came away "impressed by the work being done by Mrs Ela Bhatt and the Self-Employed Women's Association in Ahmedabad". He asked the ICFTU to "bear their work in mind", while Bhatt herself had asked him to call an experts meeting. ${ }^{96}$

SEWA planned an international campaign, helping to organize Home Net International with British and Dutch activists. ${ }^{97}$ These campaigners called

93 ILC, Record of Proceedings, Seventy-Eighth Session, 1991 (Geneva, 1992), pp. 5/2, 1/7-1/8, 1/ 12-14.

94 ILC, Record of Proceedings, Eighty-Second Session (Geneva, 1996), p. 27/51.

95 ILO, Meeting of Experts, Social Protection of Homeworkers, pp. 76-77.

96 Francis Blanchard to John Vanderveken, 18 March 1987, RL 33-3-10o, Jacket 1, ILOA.

97 Annie Delaney, "Organizing homeworkers: Women's collective strategies to improve participation and social change", PhD dissertation, La Trobe University, 2009, pp. 78-97. 
for inclusion of the informal sector's self-employed in ILO actions, but "own account" workers fell out of the resulting instruments. ${ }^{98}$ To placate governments and employers, the emerging convention and recommendation considered home workers only when they were employees, asking the many nations that failed to count home workers as such to revise their statistics. Employers, for their part, attempted to obscure the deliberations by equating industrial home workers with teleworkers, even though it was generally understood that the convention was to address conditions in developing nations and the informal sector. ${ }^{99}$ Refusing to take part in deliberations over the content of the convention, Employer delegates abstained en masse during the vote in 1996. But they failed to undermine the needed quorum. ${ }^{100}$ Rancour over the appropriateness of this action underscored the breakdown of the tripartism that had governed the ILO from the start. Convention No. 177 brought to a head, then, a long-simmering disjuncture between the organization of the ILO and the employers' negation of its procedures. In the neoliberal moment, employers wanted less, not more, oversight.

In these deliberations, the home worker appeared to be like the woman worker, covered by other conventions and equal to the hegemonic worker of the standard employment contract, but in need of special treatment because of the unique circumstance of her place of labour, the home. ${ }^{101}$ The preamble to Convention No. 177 thus spoke of "particular characteristics" and articles referred to "special characteristics", as in safety and health prohibitions. Home work happened outside of the workplace of an employer in a space of the compensated worker's choice. The employee relationship came from the employer specifying the goods or service, no matter whose "equipment, materials or

98 "Resolutions for UN Social Summit 1995 Proposed at SEwA General Body Meeting, 15-17 April 1994", pp. 5-6, EMP 63-4-1-2, Jacket 1, ILOA; “Asian Regional Workshop on the ILO Convention", EMP 63-4-1-2, Jacket 1, ILOA; "Resolution concerning self-employment promotion", in ILC, Record of Proceedings, Seventy-Seventh Session, pp. 7, 15.

99 "Report of the Committee on Home Work: Submission, discussion and adoption", in ILC, Record of Proceedings, Eighty-Second Session, p. 27/24; Governing Body, "Report of the Meeting of Experts on the Social Protection of Homeworkers", Meeting of the Governing Body, 248th Session, Geneva, 12-16 November 1990, p. III/1-2, GB 248-1—5 Gв Sess. 248, ILOA.

100 ILC, Record of Proceedings, Eighty-Second Session, pp. 252, 27/19ff; "Record of Votes", in ILC, Record of Proceedings, Eighty-Third Session (Geneva, 1996), pp. 7-10.

101 ILC, "Report of the Committee on Home Work: Submission, discussion and adoption", in Record of Proceedings, Eighty-Third Session, p. 27/21; ILO, "Home Work Convention", 1996 (No. 177), available at https://tinyurl.com/n5ayxprs, last accessed 28 August 2019. 
other inputs". But national legal and regulatory structures could define such a worker as an independent contractor, depending on the "degree of autonomy and economic independence" from the dictates of an employer. Equal treatment with others doing comparable work included "freedom of association, protection against discrimination in employment, occupational safety and health, remuneration, statutory social security protection, access to training, minimum age [guarantees], and maternity protection". To obtain these standards required additional record-keeping by employers, workers, and government agencies, as well as inspection, despite the lingering belief in the privacy of home spaces. But if other workers lacked these rights or the home work was not similar, the convention could not apply.102

Convention No. 177 emerged from the converging interests of international union federations and home worker advocates. Both wanted to end exploitation. Unions sought to protect their own gains and stop the undermining of labour standards. Like feminist and NGO campaigners, they also wanted to improve conditions for home workers. For some, improvement depended on bringing the worker to the factory; for others, it meant allowing women to earn an income while remaining in the household. ILO development feminists understood this combining of productive and reproductive labour. By recognizing the home as a workplace, they exposed the private sphere of the home as a space of public struggle.

Thirty-plus years later, we are all becoming home workers. Hours don't count, only completion of the job. In this context, a new generation of ILO staffers has found in Convention No. 177 a tool to modify abusive digital home work as well as to stem outwork in global supply chains. As the burden of production falls on "independent" contractors and other own account workers, as social protection narrows, the struggles of home-based workers offer hope that collective action, new organization, and protest might strengthen a global social wage.

102 ILC, "Report of the Committee on Home Work: Submission, discussion and adoption", pp. 27/32, 34 . 